\title{
Water Boiling Celery Affects Blood Pressure in Elderly with Hypertension
}

\author{
Erni Tri Indarti ${ }^{1}$, Lexy Oktora \\ Wilda $^{2}$, Yiyin Nuvitasari ${ }^{3}$ \\ ${ }^{1}$ Medical Surgycal Departement, \\ STIKes Satria Bhakti Nganjuk, \\ ${ }^{2}$ Geriatri Departement, STIKes \\ Satria Bhakti Nganjuk, \\ ${ }^{3}$ Student of STIKes Satria Bhakti \\ Nganjuk \\ Email: \\ triindarti77@gmail.com
}

Received : October 5, 2020

Accepted : November 22, 2020

Published : November 30, 2020

This is an open-acces article distributed under the terms of the Creative Commons Attribution-ShareAlike 4.0 International License.

\section{BACKGROUND}

One of the degenerative diseases which is a health problem in the world is hypertension (Ganong, 2008). Many elderly people who try to lower their blood pressure use chemical antihypertensive drugs instead of using herbal remedies which are cheaper, easy to obtain, natural and safe. Herbal treatment with medicinal plants does require patience and the disease does not heal by 
consuming medicinal plants for just one or two days. In addition, the elderly feel that herbal treatments cannot be as fast as chemical drugs which can quickly lower their blood pressure (Arini, et al. 2005). Based on a preliminary study conducted by researchers by giving an interview on November 13, 2019, at the Posyandu for the Elderly Bruno, Ngliman Village, Sawahan District, Nganjuk Regency, it was shown that of the 15 elderly who suffer from hypertension, 10 elderly have never consumed herbal medicine, while 5 elderly who suffer from hypertension have consuming herbal medicine with avocado leaves, meniran leaves, gotu kola leaves.

Worldwide, nearly 1 billion people or about a quarter of the adult and elderly population have high blood pressure. This number tends to increase every year (Palmer, 2007). The World Health Organization (WHO) in 2013 the prevalence in Africa (46\% of adults) while in America is the lowest prevalence, namely (35\% of adults). According to the National Basic Health Survey (2013) the prevalence of hypertension in Indonesia at 35-44 years is $24.8 \%$, 45-54 years old is 35.6\%, 55-64 years old $45.9 \%, 65-74$ years old $57.6 \%$ and over age 75 years is $63.8 \%$. The incidence of hypertension in Indonesia as much as $8.4 \%$ of the population, $69.5 \%$ aged $>75$ years, $8.8 \%$ consume drugs, $32.3 \%$ do not routinely consume drugs by reason already feel healthy so that they tend to be severe hypertension because it does not avoid and do not know the risk factor, the prevalence of hypertension in the elderly in East Java is $25.8 \%$ (Riskesdas. 2018). Based on data from the Nganjuk District Health Office, the incidence of hypertension in 2019 was 19013 people. The highest number of hypertension patient visits from all puskesmas in Nganjuk Regency was at Sawahan Health Center with an average of 95 people per month in 2019 and the number of elderly hypertension patients (aged 60 years and over) averagely 95 patients per month. Meanwhile, the number of hypertensive elderly in Posyandu for Elderly Bruno, Ngliman Village, Sawahan District was 24 elderly.

High blood pressure is commonly found in patients who are elderly (age). This is closely related to the aging process in a person. The cause of hypertension in the elderly is the occurrence of changes the elasticity of the aortic wall decreases, the heart valve thickens and becomes stiff, the ability to pump the heart decreases, loss of elasticity of blood vessels and increased peripheral vascular resistance (Laode, 2012). Structural and functional changes in the peripheral vascular system are responsible for blood pressure that occurs in the elderly. These changes include atherosclerosis, loss of elasticity of connective tissue and decreased relaxation of vascular smooth muscle. Consequently, the aorta and large arteries decrease their ability to accommodate the volume of blood pumped by the heart (volume stroke), resulting in decreased cardiac output and increased peripheral resistance (Brunner \& Suddart, 2000 accessed by Wijaya \& Putri, 2013). Hypertension must be controlled, because the longer the excessive pressure on the artery walls will result in damaging many vital organs in the body. The main places most affected by hypertension are the arteries, heart, brain, kidneys, and eyes (Suiraoka, 2012)

There are two ways of treating hypertension, namely pharmacologically and nonpharmacologically. Pharmacologists using anthihypertensive drugs such as diuretics, adrenergic inhibitors, receptor blockers (ARBs), vasodilators that act directly on the central nervous system and non-pharmacological by losing weight in obese sufferers, a diet low in salt and fat, changing life habits, exercise regularly regular as well as complementary therapies and regular blood pressure control (Laode, 2012). Non-pharmacological treatment can also use herbal remedies because there are many types of medicinal plants that are much more effective in treating several types of diseases, including chronic diseases (Herbie, 2015). Herbal therapy is a natural ingredient or plant that can help with treatment. In patients with hypertension, herbal therapy can include garlic, celery, sweet starfruit, cucumber, lime, tomato and watermelon according to Sustrani et al (2005). Celery leaves are a type of herbal therapy for treating hypertension. Traditional Chinese society has long used celery to lower blood pressure. According to (Apriliano, 2012) giving celery boiled water has been practiced by the public for a long time because celery is said to contain Apigenin which can prevent narrowing of blood vessels and Phthalides which can relax artery muscles or relax blood vessels. This content regulates blood flow which allows blood vessels to dilate and reduces blood pressure. Therefore celery can be used as an alternative choice for non-pharmacological lowering of blood pressure. Celery is high in nutrients with vitamins A, B1, B2, B6 and vitamin C. In addition, celery is rich in potassium, folic acid, calcium, magnesium, iron, phosphorus, sodium and contains lots of essential amino acids (Afridah W, 2013) . 


\section{OBJECTIVE}

The purpose of this research to determine the influence of water boiling celery against blood pressure in the elderly with hypertension.

\section{METHODS}

The research design used pre-experiment with One group pre-post test design approach. The population of all hypertensive elderly at Posyandu Elderly Bruno, Ngliman Village, Sawahan District, Nganjuk Regency with a total of 24 elderly. Held on March 2-8, 2020. Sample of 24 respondents with total sampling. The independent variable was the provision of celery boiled water, and the dependent variable was blood pressure using a sphygmomanometer. Measuring blood pressure using a sphygmomanometer (first day). Giving celery boiled water 2 x $100 \mathrm{cc}$ (morning \pm 10.00 and afternoon \pm 16.00 hours) for 7 consecutive days. On the eight day, measure blood pressure using a sphygmomanometer. The analysis used the Wilcoxon Signed Rank test through the SPSS version 16 program with $\alpha=0.05$.

\section{RESULTS}

\section{A. Characteristics Of Respondents}

Table 1. Characteristics of respondents for age, gender, education, profetion, konsumsi Obat $(\mathrm{n}=24)$

\begin{tabular}{lrr}
\hline Variables & F & $\%$ \\
\hline Age & & \\
60-74 Years & 14 & 58,33 \\
75-90 Years & 10 & 41,67 \\
>90 Years & 0 & 0,00 \\
Gender & & \\
Man & 6 & 25,0 \\
$\quad$ Woman & 18 & 75,0 \\
Education & & \\
No school & 4 & 16,67 \\
Elementary School & 18 & 75,00 \\
Middle School & 2 & 8,33 \\
High School & 0 & 0,00 \\
College & 0 & 0,00 \\
Profetion & & \\
Housewife & 7 & 29,17 \\
Farmer & 14 & 58,33 \\
$\quad$ No work & 3 & 12,50 \\
Drug consumption & & \\
$\quad$ Yes & 22 & 91,67 \\
$\quad$ No & 2 & 8,33 \\
\hline
\end{tabular}

\section{B. Blood Pressure in the Elderly}

Table 2. Tabulation of the Effect of Giving Celery Boiled Water on Blood Pressure in the Elderly 2-8 March $2020(n=24)$

\begin{tabular}{lcccc}
\hline \multirow{2}{*}{ Hipertensi } & \multicolumn{2}{c}{ Pretest } & \multicolumn{2}{c}{ Posttest } \\
\cline { 2 - 5 } & Frequency $(\boldsymbol{f})$ & Persentation (\%) & Frequency $(\boldsymbol{f})$ & Persentation (\%) \\
\hline Light & 11 & 45,83 & 20 & 83,33 \\
Moderate & 11 & 45,86 & 2 & 8,33 \\
Weight & 1 & 4,17 & 2 & 8,33
\end{tabular}




\begin{tabular}{lcccc} 
Very heavy & 1 & 4,17 & 0 & 0 \\
\hline Total & 24 & 100 & 24 & 100 \\
\hline Wilcoxon Signed Rank $p$ value & $0,035 \leq \alpha=0.05$ & & \\
\hline
\end{tabular}

\section{DISCUSSION}

Blood pressure is influenced by factors, namely age, stress, gender, and medication. Men have a higher risk of developing hypertension earlier. Men also have a higher risk of morbidity and mortality, some cardiovascular disease, whereas over the age of 50 years hypertension is more common in women. Smoking habits, being overweight are more likely to have higher blood pressure than those who are thin. In obese people, the heart will work harder to pump blood (Johnson et al, 2009)

Meanwhile, according to 'Mansjoer, 2008) men are generally more susceptible to hypertension than women. This may be because men have more factors that encourage hypertension such as stress, fatigue, and uncontrolled eating. In addition, hypertension in men occurs over the age of 31 years, while in women occurs at the age of 45 years (after menopause)

Basically celery leaves contain a lot of diuretic compounds and are thought to be able to dilate blood vessels, help the kidneys remove excess fluid and salt from the body, so that reduced fluid in the blood will lower blood pressure and as a beta blocker that can slow down the heart rate and reduce the strength of contractions heart so that blood pressure is reduced (Fausi, 2018). Meanwhile, according to Bakri (2010) celery leaves lower blood pressure because they contain flovanoids which can function as anti-oxidants which can prevent oxidation of body cells. The higher the cell oxide in the body, the higher a person is to suffer from high blood pressure. The use of celery leaves as a nonpharmacological therapy and is a plant in Indonesia that has the potential to be used as medicine.

This is consistent with research conducted by Dalimartha (2000), where the calculated Z value of systole blood pressure was -2.911 with a p-value of 0.004 in the hamlet of West Gogodalem with a percentage of 79.41.T his is because celery contains flavonoids, saponins, tannins $1 \%$ essential oil $0.033 \%$ flavor glucosides (apiin), apigenin, choline, lipase, asparagines, bitter substances, vitamins (A, B, and C) and alkaloids that can reduce levels of stress hormones in our blood. This of course allows the expansion of blood vessels, and also gives the blood more space, thereby reducing blood pressure. Celery is an herb that has been shown to lower blood pressure (Apriliano, 2012). According to Moghadam et al (2013), the community has been practicing celery for a long time, because celery leaves are said to contain Apigenin which prevents constriction of blood vessels and Phthalides which can relax artery muscles or relax blood vessels. This content regulates blood flow which allows blood vessels to dilate and reduces blood pressure. Therefore celery can be used as an alternative choice for lowering blood pressure

\section{CONCLUSION}

Water Boiling Celery Affects Blood Pressure In Elderly With Hypertension at Posyandu for Elderly Bruno, Ngliman Village, Sawahan District, Nganjuk Regency. The results of the Wilcoxon Signed Rank analysis test with $\mathrm{p}$ value $0.035 \leq \alpha(0.05)$.

\section{REFERENCES}

Afridah, W. (2013). Air Rebusan Seledri Menurunkan Tekanan Darah. Jurnal Unusa.ac.id, tgl 25 Mei 2018.

Apriliano (2012). Manfaat Seledri Bagi Kesehatan Tubuh. Retrieved from
http://apriliano.blog.com/html.

Arini, et al. (2005). Antihipertensi: Farmakologi dan Terapi. Edisi 4. Bagian Farmakologi Fakultas Kedokteran. Universitas Indonesia. 315-316. Jakarta.

Bakri B., SJ Eichhorn. (2010). Elastic Coils: Deformation Mocromechanics of Coir and Celery Fibres. Cellulose 17 (1): 1-11

Dalimartha, S., 2004, Resep Tumbuhan Obat untuk Asam Urat, 1-2. Jakarta: Penebar Swadaya.

Fausi, A. (2018). Pengaruh Pemberian Air Rebusan Seledri Terhadap Penurunan Tekanan Darah Pada penderita Hipertensi. repo.stikesicme-jbg.ac.id

Ganong, W. F. (2008). Buku Ajar Fisiologi Kedokteran. Edisi 22. Jakarta: EGC. 
Herbie, T. (2015). Kitab Tanaman Berkhasiat Obat. Yogyakarta: CV. Solusi Distribusi.

Johnson, Feig, Nakagawa \& Lozado.(2009).Pathogenesis of essential hypertension: historical paradigms and modern insights. J Hypertens March; 26(3):381-391.

Laode, S. (2012). Asuhan Keperawatan Gerontik. Yogyakarta: Nuha Medika.

Mansjoer, A. dkk. (2008). Kapita Selekta Kedokteran. Jakarta: FKUI

Moghadam, Imenshahidi and Mohajerin. (2013). Antihypertensive effect of celery seed on rat blood pressure in chronic administration. Journal of Medicinal Food 16(6):558-563.

Palmer A. W. B. (2007). Tekanan Darah Tinggi. Jakarta: Erlangga.

Riskesdas Depkes. (2018). Riset Kesehatan Dasar. Jakarta: Badan Penelitian dan Pengembangan Kesehatan Depkes RI

Suiraoka, I. P. (2012). Penyakit Degeneratif. Denpasar: Nuha Medika.

Sustrani., Lanny., et al (2005). Hipertensi. Jakarta: PT Garmedia Pustaka Utama

WHO. (2013). About Cardiovascular diseases. World Health Organization. Geneva. Cited July $15^{\text {th }}$ 2014. Retrieved from: http://www.who.int/cardiovascular_diseases/about_cvd/en/accessed on.

Wijaya, A.S., Putri, Y. S. (2013). Keperawatan Medikal Bedah 1 (Keperawatan Dewasa). Yogyakarta: Nuha Medika. 